Bidik: Jurnal Pengabdian kepada Masyarakat |Vol. 2 No. 1 Oktober 2021

Doi: https://doi.org/10.31849/bidik.v2i1.5668

\title{
Edukasi Pembuatan Video Media Pembelajaran Paud Menggunakan Komputer Bagi Tenaga Pendidik PAUD Lilik Kecamatan Bukit Raya
}

\author{
Roki Hardianto*, Wirdah Choiriah, Fana Wiza \\ Prodi Teknik Informatika, Fakultas Ilmu Komputer, UNiversitas Lancang Kuning \\ *Email: roki@unilak.ac.id
}

\begin{abstract}
In this activity, educators at the Lilik PAUD School which is located at Air Cold Village, Bukit Raya District, Pekanbaru City are taught about making learning media in the form of computer-enabled videos. So far, educators have used learning media manually by utilizing cardboard and pictures made independently by the teacher. During the Covid-19 pandemic, teachers had difficulties in making learning media that could be applied in online learning. This activity was initiated by the Association of Indonesian Early Childhood Educators and Education Personnel (HIMPAUDI) Bukit Raya District. The output of this activity is in the form of products made by training participants, scientific journals of activity results, news of activities published on online media and teacbing modules that can be used by teachers.
\end{abstract}

Keywords: OBS Studio, IT, PAUD, Covid-19, E-Learning

\begin{abstract}
Abstrak
Pada kegiatan ini tenaga pendidik di Sekolah PAUD Lilik yang beralamat di Kelurahan Air Dingin Kecamatan Bukit Raya Kota Pekanbaru diajarkan tentang membuat media pembelajaran dalam bentuk video yang bisa komputer. Selama ini pada tenaga pendidik menggunakan media pembelajaran secara manual dengan memanfaatkan kertas karton dan gambar-gambar yang dibuat mandiri oleh guru. Selama masa pandemic Covid-19, para guru kesulitan dalam membuat media pembelajaran yang dapat diterapkan dalam pembelajaran daring. Kegiatan ini di inisiasi oleh Himpunan Pendidik Dan Tenaga Kependidikan Anak Usia Dini Indonesia (HIMPAUDI) Kecamatan Bukit Raya. Luaran kegiatan ini adalah berupa produk yang dibuat oleh peserta pelatihan, jurnal ilmiah hasil kegiatan, berita kegiatan yang terbit pada media online dan modul ajar yang bisa dimanfaatkan guru.
\end{abstract}

Kata kunci: OBS Studio, IT, PAUD, Covid-19, E-Learning

\section{Pendahuluan}

Sekolah Pendidikan Anak Usia Dini (PAUD) Lilik beralamat Jalan Datuk Wan Abdurrahman No.70, Simpang Tiga, Kec. Bukit Raya, Kota Pekanbaru. Merupakan sekolah PAUD yang memilik 3 tingkatan sekolah yaitu Taman Kanak-Kanak (TK), Kelompok Bermain (KB) dan Taman Penitipan Anak (TPA). 


\section{Gambar 1. Kegiatan Pagi PAUD Lilik}

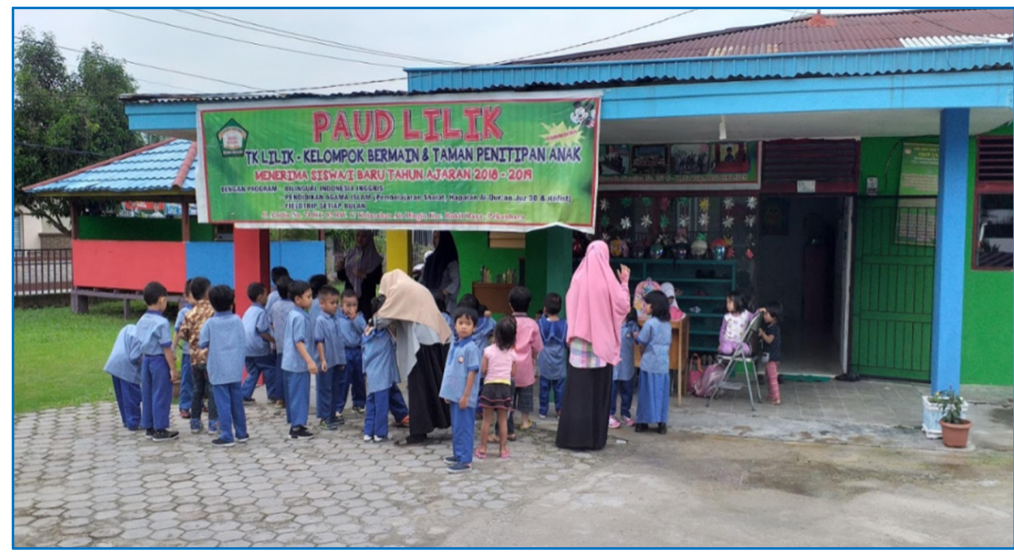

Tenaga Pendidik PAUD Lilik adalah berasal dari lulusan S1 PAUD Universitas Lancang Kuning dan beberapa perguruan tinggi di Provinsi Riau serta lulusan setingkat SMA. Jumlah siswa di PAUD Lilik lebih kurang 150 siswa. PAUD Lilik tergabung dalam organisasi HIMPAUDI (Himpunan Pendidik Dan Tenaga Kependidikan Anak Usia Dini Indonesia) di Kecamatan Bukit Raya. Organisasi ini mengakomodir sekolah dalam proses pembelajaran lebih baik untuk memajukan sekolah dan sebagai wadah aspirasi bersama. Tenaga Pendidik PAUD Lilik masih minim dalam pemahaman penggunaan computer dalam membuat dan mendesign media pembelajaran. Media pembelajaran masih dibuat secara manual menggunakan kertas lipat dan sejenisnya.

\section{Gambar 2. Kegiatan Belajar Bersama Dihalaman Sekolah}

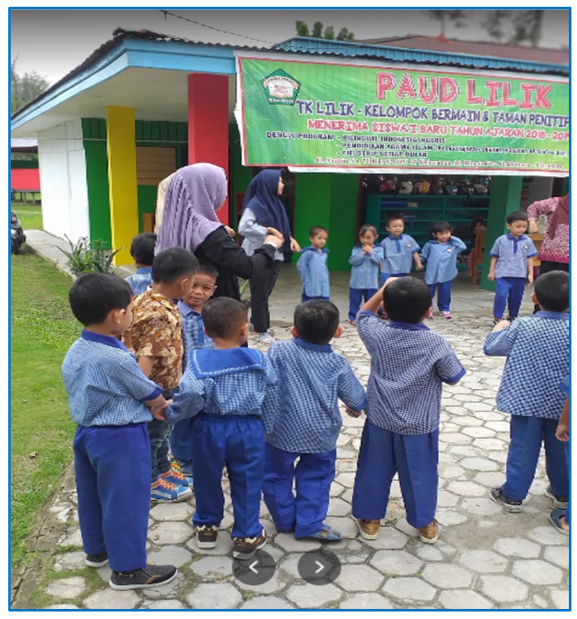

Dimasa Pandemi Covid-19 proses pembelajaran di PAUD Lilik sangat terkendala karena pemerintah mewajibkan pembelajaran secara daring, hal ini untuk menghambat penyebaran Covid19 serta menjaga anak-anak siswa tetap aman dan sehat. Tingkat kemampuan penggunaan computer dan internet oleh tenaga pengajar masih minim. Termasuk membuat media pembelajaran secara digital sebagai penunjang pembelajaran daring menjadi terkendala. 


\section{Pendekatan Pelaksanaan Program}

Metode pelaksanaan Pengabdian Kepada Masyarakat adalah dengan menggunakan metode praktek. Pada tahapan awal, narasumber akan menjelaskan tentang materi dan topik Pengabdian Kepada Masyarakat kepada peserta pelatihan. Kemudian akan dijelaskan aplikasi pendukung yang digunakan dalam membuat media pembelajaran digital dalam bentuk video. Alat dan bahan yang dibutuhkan dalam membuat media pembelajaran digital adalah (1) Komputer; (2) OBS Studio; (3) Slide Presentasi dari Ms. Powerpoint; (4) Gambar pendukung ( https://www.canva.com/ ).

Peserta dipandu cara mendownload OBS Studio dan menginstalnya di komputer peserta. Kemudian peserta diminta membuat media pembelajaran dalam bentuk slide presentasi menggunakan Ms Powerpoint. Kemudian peserta diarahkan melakukan proses pembuatan video dengan aplikasi OBS Studio dengan melakukan setting Langkah-langkah perekaman hingga menjadi sebuah media pembelajaran dalam bentuk video.

Diawal pelaksanaan Pengabdian Kepada Masyarakat peserta diminta mengisi angket untuk melihat tingkat pemahaman peserta terhadap tema Pengabdian Kepada Masyarakat. Kemudian diakhir peserta juga mengisi angket tentang tingkat pemahaman terhadap materi Pengabdian Kepada Masyarakat.

\section{Pelaksanaan Program}

Pelaksanaan kegiatan Pengabdian Kepada Masyarakat dilaksanakan secara langsung di PAUD Lilik pada hari Sabtu, 3 Juli 2021 jam 09.00 WIB. Hadir sebagai peserta adalah ketua Yayasan Lembaga Pendidikan Salsabilla, para guru dan tenaga pengajar PAUD Lilik termasuk kepala sekolah sebanyak 8 orang.

Tema dari Pengabdian Kepada Masyarakat adalah "Edukasi Pembuatan Video Media Pembelajaran Paud Menggunakan Komputer Bagi Tenaga Pendidik PAUD Lilik Kecamatan Bukit Raya". Maksudnya adalah guru dan tenaga pengajar PAUD Lilik diajarkan materi membuat video pembelajaran menggunakan aplikasi OBS Studio dengan memanfaatkan komputer.

Aplikasi OBS Studio adalah sebuah aplikasi Open Broadcaster Software Studio yang biasa digunakan dalam membuat dan mengolah video dengan kreatif untuk hal live webinar dari social media atau video offline. Dengan aplikasi ini pengguna dapat membuat sebuah video pembelajaran yang kreatif dan inovatif dengan mengkombinasikan beberapa aplikasi lain seperti power point atau gambar yang menarik. Aplikasi ini dapat di download pada link https://obsproject.com/ secara gratis. 
Gambar 3. Sambutan Ketua Yayasan Lembaga Pendidikan Salsabilla

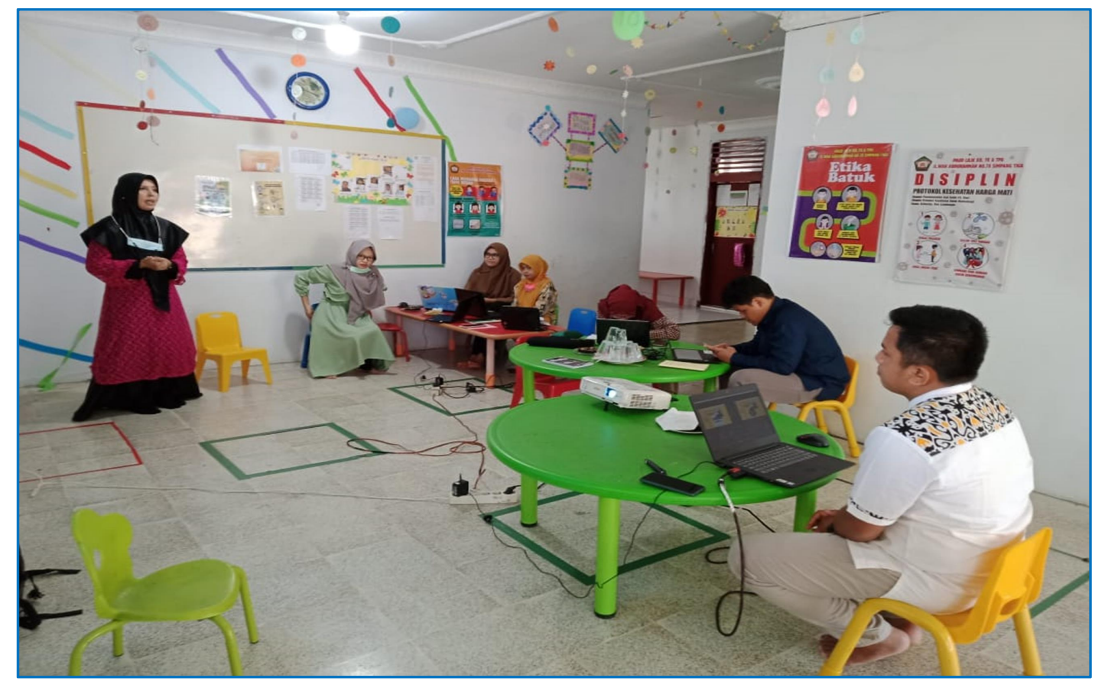

Pada proses pembelajaran khususnya selama Pandemi Covid-19, PAUD Lilik sudah menggunakan video pembelajaran yang dishare kepada siswa dan orang tua siswa melalui aplikasi https://new.edmodo.com/home. Video pembelajaran dibuat menggunakan handphone dengan sentuhan editing sederhana oleh guru.

Pihak sekolah mengaku video pembelajaran yang dibuat oleh guru dalam proses pembelaran selama pandemic Covid-19 sangat tidak efektif karena sebelumnya mereka tidak pernah mendapatkan pelatihan tentang pembuatan video pembelajaran. Dengan kegiatan pelatihan ini Ketua Yayasan Lembaga Pendidikan Salsabilla sangat berharap dapat membantu para guru dalam mengupgrade wawasan dibidang IT khususnya dalam pembuatan media pembelajaran dalam bentuk video.

Narasumber kegiatan ini adalah Roki Hardianto, M.Kom sekaligus ketua Pengabdian Kepada Masyarakat. Diawal kegiatan penjelasan tentang teknik dan trik membuat bahan ajar dari Microsoft Office Powerpoint dengan tema yang menarik karena siswa yang akan diajar adalah siswa tingkat usia dini yang cenderung lebih suka dengan gambar dan animasi yang menarik. Hal ini perlu dilakukan karena guru di PAUD Lilik tidak ada backgroundnya dari jurusan IT atau pernah mengecap pendidikan berbasis IT. https://www.canva.com/ adalah website yang biasa digunakan untuk membuat slide yang menarik dengan animasi keren-keren. Pada website itu guru bisa mendapatkan gambar yang sesuai dengan tema pembelajaran siswa. 


\section{Gambar 4. Peserta Sedang Diskusi Dengan Narasumber}

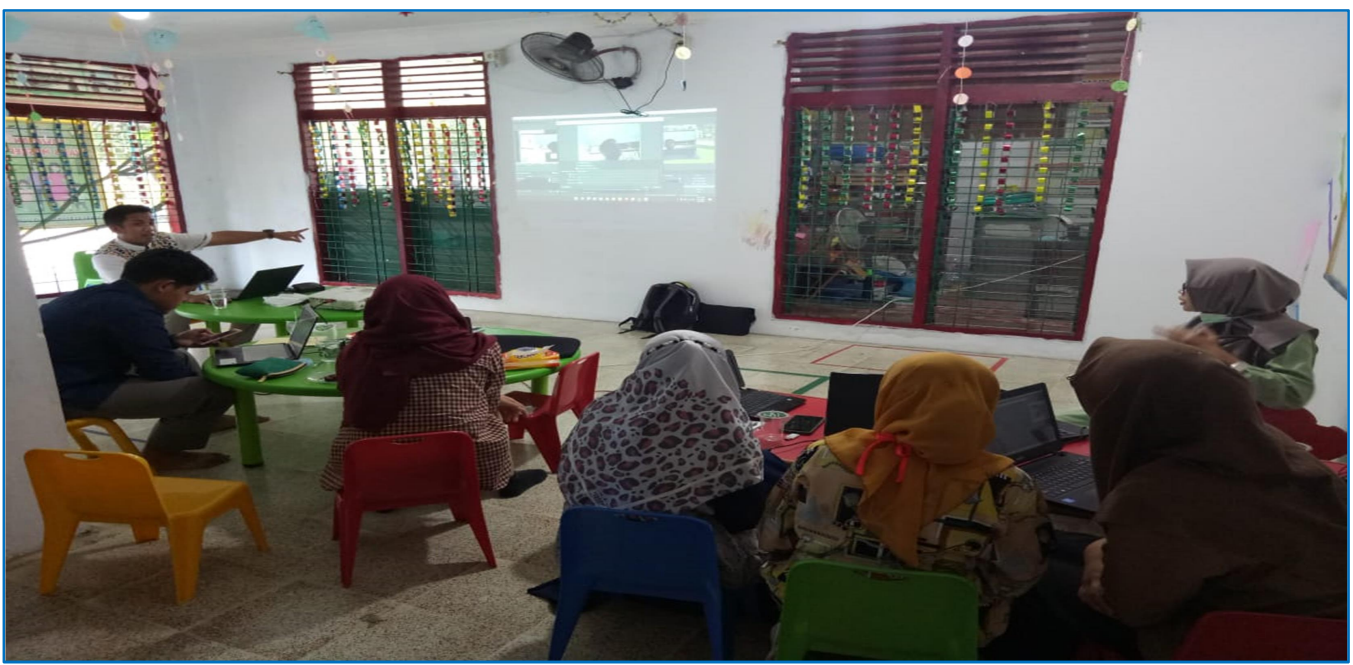

Dalam pelaksanaan kegiatan, untuk melihat tingkat pemahaman peserta dalam penerapan materi yang disampaikan narasumber maka disebarkan angket dengan hasil sebagai berikut:

1. Apakah pelatihan ini menambah wawasan anda sebagai peserta?

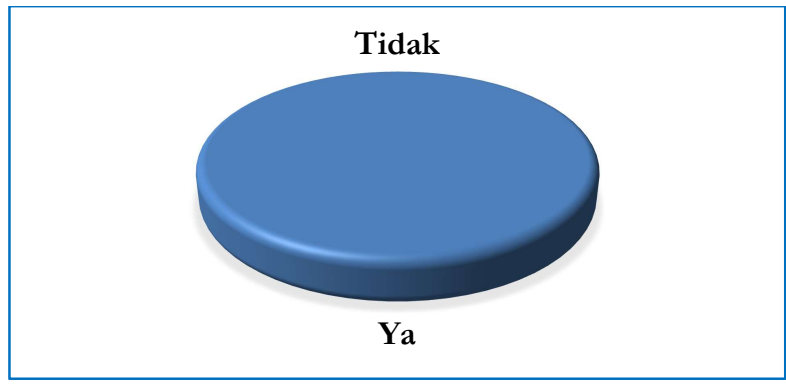

2. Terhadap materi pelatihan, bagaimana pemahaman anda?

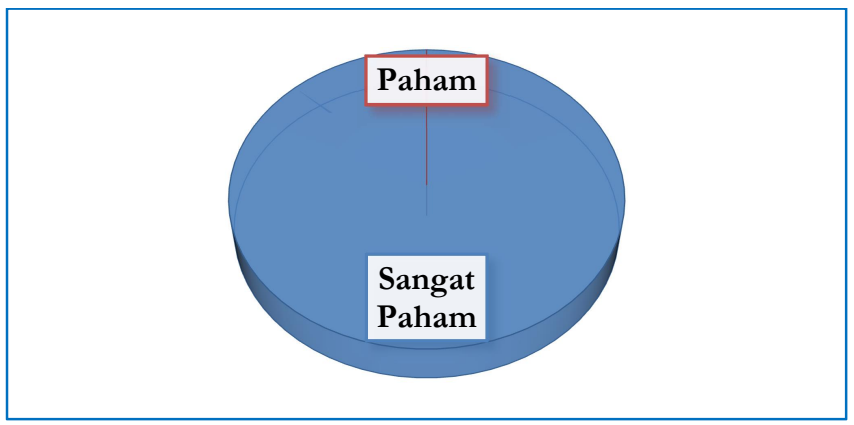

3. Apakah saudara sudah pernah mendapatkan materi yang sama sebelumnya? 


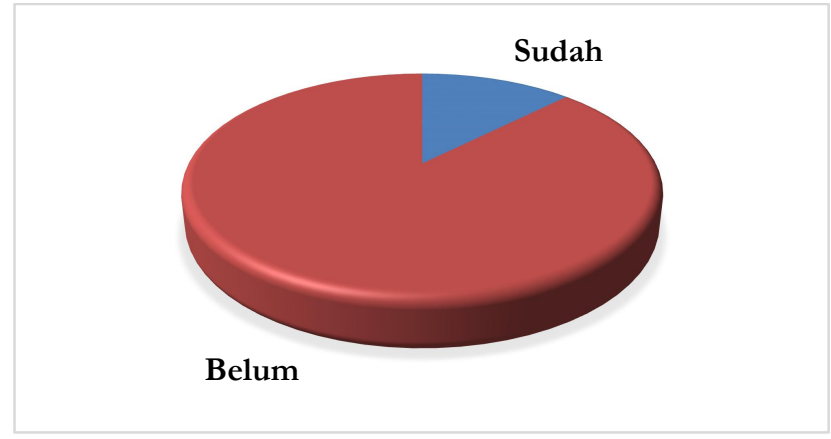

4. Jika dilakukan praktik, apakah saudara mampu membuat sebuah video pembelajaran sederhana?

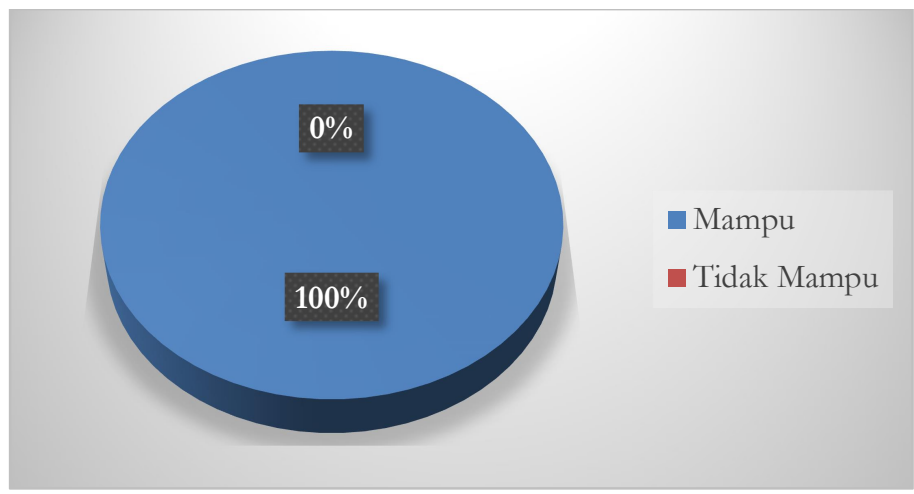

Dari 4 pertanyaan angket yang diajukan maka dapat ditarik kesimpulan bahwa peserta mendapatkan pengetahuan baru dibidang IT khususnya membuat media pembelajaran dalam bentuk video dengan aplikasi OBS Studio. Selama ini ternyata peserta belum pernah mendapatkan wawasan / pelatihan dengan materi yang sama dengan kegiatan saat ini. Peserta mampu membuat dengan sendiri video pembelajaran untuk kegiatan pembelajaran daring.

Dari kegiatan pengabdian kepada masyarakat, luaran yang di capai adalah

1. Publikasi Berita Kegiatan

Berita kegiatan yang di terbitkan pada media berita online sapa riau pada link

http://www.sapariau.com/berita/detail/dosen-unilak-berikan-edukasi-pembelajaran-

berbasis-it-kepada-guru-paud-lilik, 
Gambar 5. Publikasi Kegiatan Pada Media Online Sapa Riau

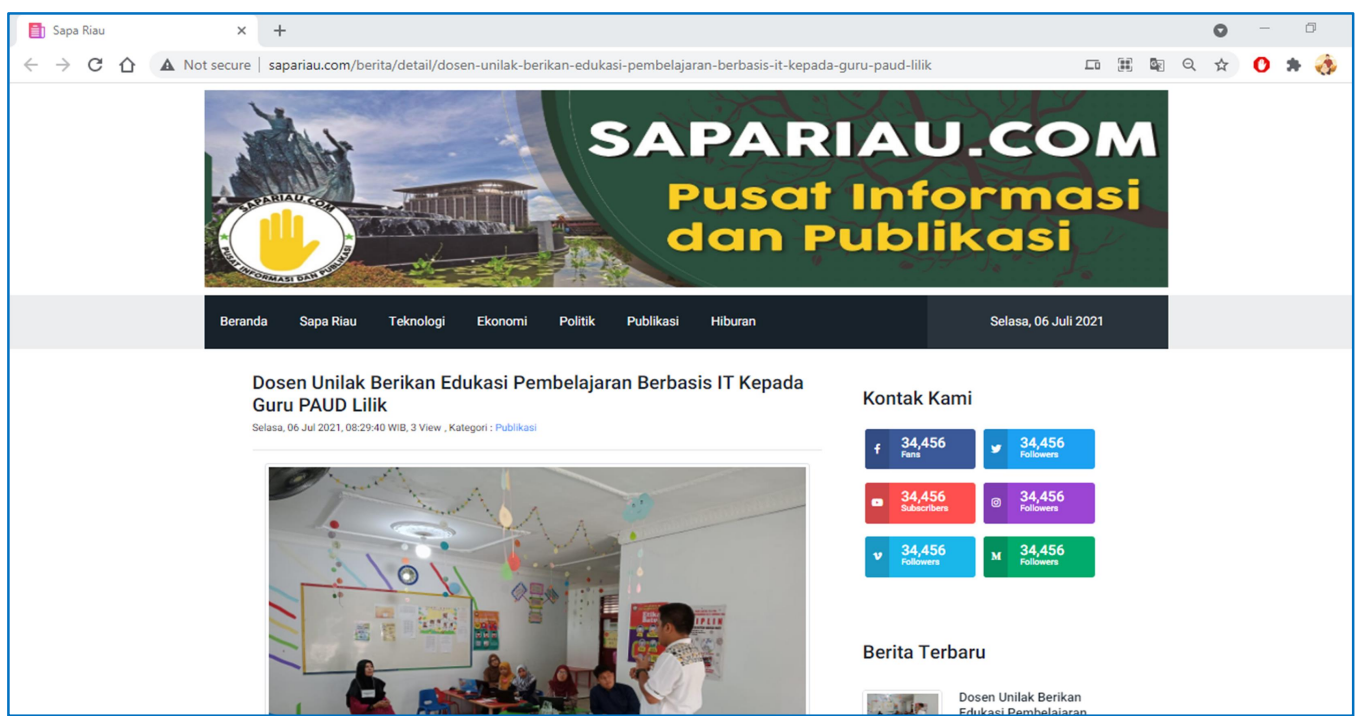

Berita kegiatan yang di terbitkan pada media berita online sapa riau pada link https://uvdona.com/dosen-unilak-berikan-edukasi-pembelajaran-berbasis-it-kepada-guru-paud$\underline{\text { lilik/ }}$

Gambar 6. Publikasi Kegiatan Pada Media Online Uvdona

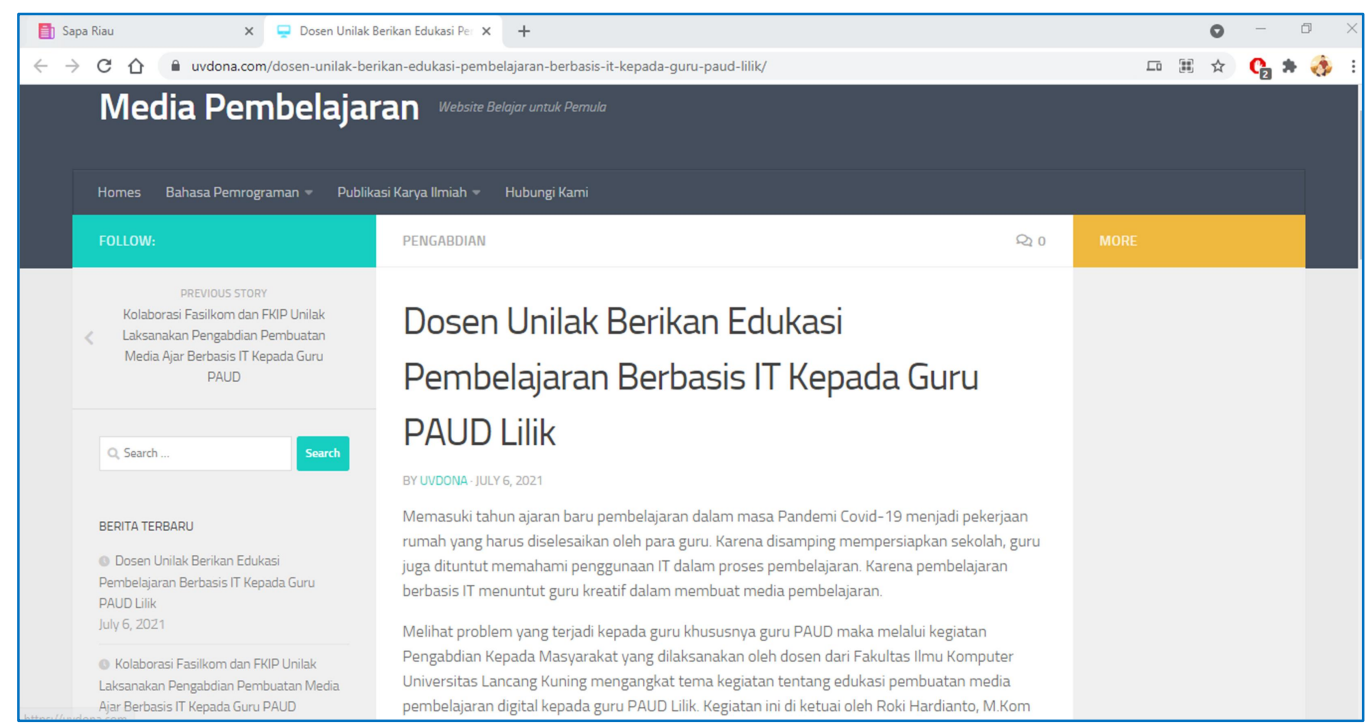

Selain itu juga terbit pada website Fakultas Ilmu Komputer Universitas Lancang Kuning https://fasilkom.unilak.ac.id/berita/detail/dosen-unilak-berikan-edukasi-pembelajaran-berbasis-itkepada-guru-paud-lilik 
Gambar 7. Publikasi Kegiatan Pada Website Fakultas Ilmu Komputer
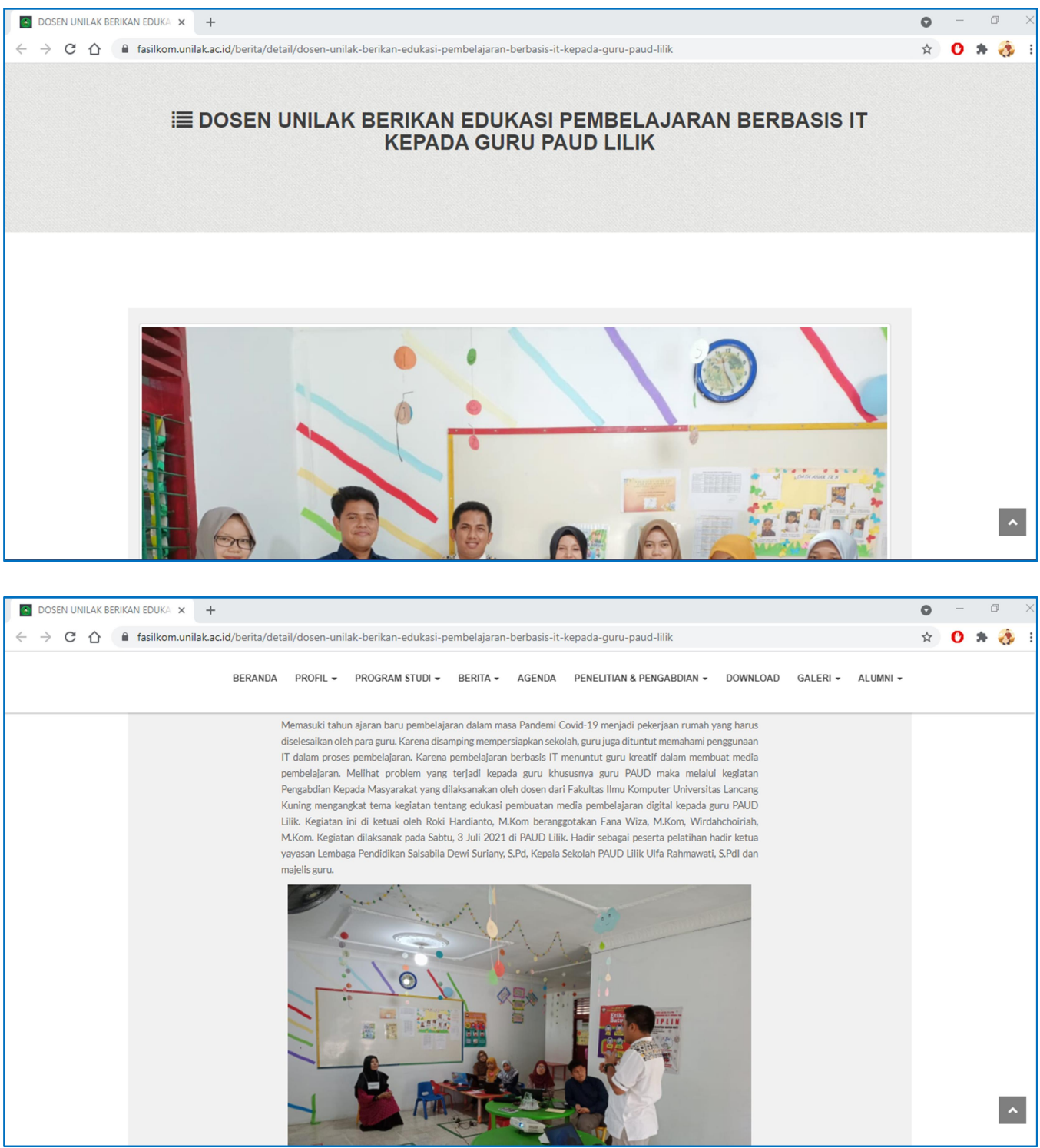

Tujuan dari berita adalah untuk mempublikasikan kegiatan Pengabdian Kepada Masyarakat yang telah dilaksanakan sebagai kegitan Tri Dharma Perguruan Tinggi dosen kepada masyarakat. Berita kegiatan dapat disebarluaskan dengan menggunakan social media berupa facebook, twitter, Instagram, whatsapp dan lainnya.

\section{Refleksi Capaian Program}

Kegiatan Pengabdian Kepada Masyarakat ini yang telah dilaksanakan pada PAUD Lilik dengan topik pembuatan media pembelajaran berbasis IT menggunakan OBS Studio. Pada kegiatan ini guru PAUD Lilik diajarkan menggunakan aplikasi OBS Studio untuk membuat video pembelajaran sebagai penunjang pembelajaran secara daring menggunakan e-learning dalam hal ini 
https://new.edmodo.com/ dan sosial media whatsapp. Output media pembelajaran dari penggunaan aplikasi OBS Studio adalah sebuah video pembelajaran.

Kegiatan ini dilaksanakan dengan baik dengan capaian materi adalah 90\% peserta memahami penggunaan aplikasi OBS Studio dan mampu membuat video pembelajaran secara mandiri. Kegiatan ini harus dilaksanakan secara rutin agar dapat tetap meningkatkan pemahaman dan kemahiran penggunaan aplikasi OBS Studio dan pemahaman penggunaan aplikasi editing video seperti filmoora, adobe premier atau aplikasi editing sejenis.

\section{Penutup}

Berdasarkan hasil pelaksanaan Pengabdian Kepada Masyarakat dengan tema "Edukasi Pembuatan Video Media Pembelajaran Paud Menggunakan Komputer Bagi Tenaga Pendidik PAUD Lilik Kecamatan Bukit Raya" adalah

1. Sekolah mengapresiasi kegiatan karena mampu meng-upgrade wawasan guru terhadap IT

2. Kegiatan sangat membantu karena guru dapat membuat media pembelajaran menggunakan powerpoin dengan desain dan animasi yang menarik, karena sebelumnya hanya menggunakan handphone untuk merekam guru saat menjelaskan materi

3. Peserta kegiatan antusias dan mampu menerapkan materi yang diajarkan kepada kegiatan pembelajaran daring

Berdasarkan pelaksanaan kegiatan Pengabdian Kepada Masyarakat yang dilaksanakan di

PAUD Lilik maka ada beberapa saran terhadap kegiatan kedepan, diantaranya :

1. Kegiatan yang serupa untuk dapat dilakukan secara rutin

2. Memperdalam topik kegiatan berkaitan dengan hal umum dalam penggunaan IT, seperti penggunaan Microsoft Office dan sejenisnya

3. Kami dari PAUD Lilik selalu siap menerima pengetahuan baru di bidang IT.

\section{Daftar Pustaka}

Ayuni, D., Marini, T., Fauziddin, M., \& Pahrul, Y. (2020). Kesiapan Guru TK Menghadapi Pembelajaran Daring Masa Pandemi Covid-19. Jurnal Obsesi $\square$ : Jurnal Pendidikan Anak Usia Dini, 5(1), 414. https://doi.org/10.31004/obsesi.v5i1.579

Dawolo, A., Zulafwan, \& Saputra, H. T. (2018). Indonesian Journal of Electrical Engineering and Computer Science. STMIK Indonesia Padang, 7(1), 92-100.

Efendi, Y., Rio, U., Syaifullah, M., \& Imardi, S. (2020). J-PEMAS STMIK Amik Riau Pelatihan Multimedia Learning Dalam Pembuatan Konten Media Kreatif. 1(1), 1-3.

Kurnia, R., \& Kurnia, R. (2020). PAUD Lectura: Jurnal Pendidikan Anak Usia Dini, Vol 4, No 1, Oktober 2020. 4(1), 32-41. https://doi.org/10.31849/paud-lectura.v

Mustakim. (2020). Efektivitas Pembelajaran Daring Menggunakan Media Online Selama Pandemi Covid-19 Pada Mata Pelajaran Matematika the Effectiveness of E-Learning Using Online Media During the Covid-19 Pandemic in Mathematics. Al Asma: Journal of Islamic Education, 2(1), 1-12. 
Pramudyani, A. V. R. (2020). The Effect of Parenting Styles for Children's Behaviour on Using Gadget at Revolution Industry. Jurnal Obsesi $\square$ : Jurnal Pendidikan Anak Usia Dini, 5(1), 51. https://doi.org/10.31004/obsesi.v5i1.520 